\title{
EFL STUDENTS' ENGAGEMENT DURING INTERACTIVE READ ALOUD
}

\author{
Fadillah Sandy \\ Universitas Muhammadiyah Magelang \\ Fadillah.sandy@ummgl.ac.id \\ Laksananing Mukti \\ SMA Taruna Nusantara \\ lmukti@yahoo.com
}

\begin{abstract}
This study explores EFL students' engagement during interactive read-aloud activities. Students' engagement was observed in two meetings (Mean= 70 minutes). The subject of this research was the $10^{\text {th }}$ grade of high school students. The data was taken from the teacher's field notes and the students' essays $(n=32)$. The teacher's field notes were used as a tool to see how interactive read-aloud was applied, while students' essays were used to gather the students' writing performance and language functions. The result shows that in behavioral engagement, the students were very much engaged during the classroom activity. As in cognitive engagement, it could be seen that the students used to mix languages in delivering their idea in spoken, while in writing, most of the students had excellent ability to elaborate their idea. Students showed their affective engagement through their excitement and eagerness while listening and discussing storybook during interactive read-aloud.
\end{abstract}

Keywords: EFL, students' engagement, interactive read-aloud

\section{BACKGROUND}

In Indonesia, there is still little attention from the government and scholars to promote engaging reading activities for children. In 2016, the reading habit in Indonesia was at the $60^{\text {th }}$ of 61 countries who participated in the study of The World's Most Literate Nations conducted by UNESCO. Reading has not yet been part of the people's habit, and it affects the children's habit too since children hardly get exposure to interactive reading with parents or adults. Research findings also showed that students' reading motivation is also an international issue. Gambrell (2011) noted that $37 \%$ of students did not read for enjoyment as it was reported from the Program for International Student Assessment (PISA) across 64 countries. The same program also reported that students who enjoyed reading performed better than those who didn't. Also, In Gambrell's article (2011), she found out that the students' reading interest predicted their reading comprehension. Meanwhile, according to PISA 2015, the reading performance of Indonesian 15 years old students was at number 63 among 72 countries who contributed to the research. As such, it is very crucial to elevate Indonesian students' reading performance as well as their motivation to read by creating an engaging and meaningful reading activity. 


\section{Engagement in Reading}

Most recently, engagement has been conceptualized as a multidimensional construct, consisting of behavioral (time on task), cognitive (strategic effort), and affective (interest in the topic and task) components (Fredricks, Blumenfeld, \& Paris, 2004; Malloy, Parsons, \& Parsons, 2013; Parsons, Nuland, \& Parsons, 2014). Furthermore, Parsons et al. (2015) explained behavioral engagement is related to effortful participation; cognitive engagement covers strategic behavior, persistence, and meta-cognition, while affective engagement stresses interest, enjoyment, and enthusiasm.

In 2009, the Program for International Student Assessment (PISA) conducted a study in which approximately 470,000 students completed the assessment in the form of a questionnaire representing the United States, Ireland, Germany, Finland, and Korea. The questionnaire gathered data on three aspects of reading engagement: (1) enjoyment of reading, (2) time spent reading for enjoyment, and (3) diversity of texts read (i.e., a single type of text, such as newspapers, versus a wide variety of texts, such as newspapers, magazines, fiction, nonfiction, etc.). From the survey, Brozo et al. (2014) noted a trend that girls' reading literacy achievement and engagement were significantly higher than boys. The international survey from PISA addressed three aspects of engagement which cover, the three-multidimensional construct of engagement: (1) enjoyment as affective dimension, (2) time spent as behavioral dimension, and (3) diversity of texts as cognitive dimension.

Engagement, as one of the key factors of students' success in learning has broadly, defined and examined in many educational research contexts. According to Skinner and Pitzer (2012), it is "a robust predictor of students' learning, grades, achievement test scores, retention, and graduation" (p. 21). In reading context, Guthrie and other distinguished scholars focused their studies on examining the correlation of four variables of students' engagement, motivation, reading skills, and reading achievement across various ages and different genders. Ivey and Johnston (2013) noted that engagement is a pivotal component of classroom reading instruction, for it is correlated explicitly with students' reading achievement.

Furthermore, engagement is also theoretically and practically related to motivation. In reading, motivation may be regarded as "reasons for reading" (Guthrie and Klauda, 2014) while engagement refers to the joint functioning of motivations and strategies during reading (Newman, Wehlage, and Lamborn, 1992). Guthrie et al. (1996) also defined engagement as the integration of intrinsic motivation, cognitive strategies, and conceptual learning from text. In their oneyear study, they found out that increases in literacy engagement during the year were tied to increases in intrinsic motivation. However, it was not determined which one came first; the relation between engagement and motivation in their study was more reciprocal and mutual. In another study, Guthrie and Klauda (2014) also described engaged readers in their study as students who were energized by internal motivation such as intrinsic motivation, value, and perceived competence. Their study also showed a significant correlation of engagement and motivation practices across the three times period of their study. As previous studies showed their mutual correlation, it is crucial to enable engaging and motivating reading instructions in order to increase students' reading achievement and motivation in the classroom. 


\section{Interactive Read-Aloud}

Read-aloud is defined as an instructional reading practice in which teachers or parents read the text aloud to children by incorporating pitch, tone, pace, volume changes, questions, and comments to produce fluent and engaging delivery Johnston (2016). Reading aloud as one of the notorious reading strategies in the United States is promoted both at family and school levels. It becomes part of a reading habit that can accommodate parent-children interaction during reading. Trealease (2013) noted that nine-year-old American children's interest in reading at that level is among the best in the world. However, research found that in these past thirty years, read-aloud wasn't seen to be genuinely communicative and combined with often misuses (Gibson, 2008). Thus, Pinnell et al. (2001) argued that there should be intentional and ongoing active invitations to the students to respond and interact with the oral reading of the story through interactive read-aloud. As such, Interactive Read-Aloud (IRA) is defined as a read-aloud activity that enables discussion to promote students' active listening, speaking, and critical thinking and to help them develop their linguistic features as they engage with text (Sandy and Muliawanti, 2020).

Several research projects explored how interactive read-aloud was implemented in more diverse language classrooms and contexts. In America, the study of interactive reading was focusing on how it could affect children's linguistic features. Researchers found that IRA could increase children's reading performance and vocabularies (Toth, 2013; Silverman, Crandell, and Carlis, 2013). Meanwhile, in a more diverse classroom, the discussion during IRA helped children to expose their bilingual language skills in speaking (Oueini et al., 2008, and Worthy et al., 2013).

The studies showed how interactive read-aloud conducted in diverse classroom contexts. It could successfully increase students' vocabulary mastery and helped making sense words in context. It also could create an engaging space to explore English texts using hybrid languages in a bilingual classroom since the teacher and the students were able to interact comfortably by shifting their languages. Meanwhile, studies in engagement presented its pivotal role in classroom reading instruction. In addition, several researches noticed that engagement could enable students' intrinsic motivation during reading activities. However, none of the studies could exhibit how interactive read-aloud in EFL classrooms could help students engaged and motivated. In Indonesia, especially, it is very important to facilitate an engaging reading space while making sense English texts in order to develop their critical thinking and motivation. It is expected that interactive read-aloud can aid EFL teachers in creating an engaging reading activity in their classroom. As such, this study explores engagement portrayed during interactive read-aloud in an EFL classroom.

\section{METHOD}

\section{Participants}

The participants of this study were the $10^{\text {th }}$ grade students of a private Senior High School in Indonesia. It is a boarding school with a very diverse mixed class group of students. The students were coming from mostly all provinces around 
Indonesia. The classroom was particularly chosen for its time availability and diverse students' English language performance. In the first meeting and second meeting, there were 25 students and 32 students.

\section{Instruments}

Observation. Students' engagement during interactive read-aloud were explored through observation as they participated in interactive read-aloud activity. The observation was conducted twice in which at the first meeting it was 75 minutes while the second meeting was 65 minutes. The different time spent on each meeting was due to on unpredicted school's agenda on each week. Both sessions were documented in form of teacher's field notes. After the class, each of the observations was noted right away to gather as much information as possible about the classroom condition.

Data. The data in this study was in form of teacher's field notes and students' essays. Notes were used as a primary data to describe students' responses to interactive read-aloud and their engagement. Every note was taken right after the end of classroom activity to provide a more vivid memory and in-depth descriptions about what was happening during the instruction. And, students' essays were collected in the second meeting from each of the students. According to McMillan (2014), an excellent way to measure deep understanding and mastery of complex information is using an essay. In this task, students were asked to write a half-page of essay about their responses of the story told during the interactive read-aloud. This task was at the end of the second meeting as the whole story of Amos and Boris had been read to the students. A holistic scoring guide was made by the researcher to assess overall students' performance in delivering their thoughts in a written language (McMillan, 2014). At the end, this essay would be useful as one of the supportive data sources to show their engagement during the interactive read-aloud.

Preparation. The researchers worked intensively and collaboratively with the home teacher to prepare this study and gathered information on the students' background and language development. Based on the 2013 National Curriculum, fable was one of the reading topics for $10^{\text {th }}$ grade Senior High School students. In addition, using narrative text such as fable is a meaningful start to promote engagement and interactive discussion (Hoffman et al., 2015). As a result, a book, Amos and Boris (Steig, 1971), was selected as the main reading in Interactive ReadAloud while one of the Aesop's fable collection, The Lion and The Mouse (Pinkney, 2000) was provided in the second meeting as an additional comparative reading for students. The two readings were selected as they provide universal theme and complex perspectives as well as suitable language level for the students.

\section{Data Analysis}

Area of Analysis. The teacher's field notes, and students' essays were analyzed qualitatively. Students' engagement was seen based on the three multidimensional constructs of behavioral, cognitive, and affective. The behavioral engagement explored students' time spent during interactive read aloud, the cognitive engagement saw students' performance in spoken and written texts, and the affective engagement observed students' participation in reaction to the reading activity. 
Teacher's Field Notes. Notes from the first meeting were read closely and repetitively to identify plausible findings as well as limitations for further improvement for the next meeting. At the end, all notes were gathered as a tool to help develop an elaborative description of how the interactive read-aloud was applied in an Indonesian EFL classroom.

Students' essays. Each of the students' essay was analyzed in two phases. First, the rubric was used to gather overall students' written English performance in terms of content, organization, and use of language. Second, each sentence was analyzed to classify its function(s). The list of language functions used was adapted from Halliday (1975) and Bloome (1989) in examining spoken text. Although the list referred to spoken text analyses, Fairclough (2003) argued that the functions applied to any type of texts, including written texts because all text types, spoken or written, imply and are oriented to dialogue in a broad sense. From the analysis, there were 226 sentences from 32 students' essays. Each of the sentences was analyzed as to their type of function for each sentence. In this analysis, each sentence might have more than function since a long sentence might have more than one function at the same time. For example, one student wrote, "I think the story has a very valuable moral value because it really shows how differences can make a strong friendship between two creatures." The first phrase, "I think the story has a very valuable moral value" was functioned as an opinion and the following phrase was as a reasoning that supported his opinion. There were nine language functions appeared in students' essays: giving an opinion, making connections to the reading, making connections to other readings, making connections to one's experience/real life, reasoning, inferencing, elaborating, giving examples, and persuading/giving suggestions. Each sentence might expose more than one function and each function was scored 1. At the end, all the quantitative data from this analysis was described qualitatively to explain how students' written language could exhibit their engagement in interactive read-aloud.

\section{FINDINGS AND DISCUSSION}

\section{Behavioral Engagement}

Table 1 presents students' time spent on every type of activities in the first and second meetings. Students spent most of the time in discussion which took $60 \%$ of the first meeting and $61.5 \%$ of the second meeting (Mean $=60.7 \%, 42.5$ minutes). From the teacher's observation, most of the students were participated in the discussion as their response to teacher's guidance. For example, in the first meeting's ice breaking, students were asked to step inside and outside a circle to respond to teacher's statement about their prior knowledge about fable. All of the students were stepping inside to respond to the statement of "step inside if you know about fable!"

Students also spent $40 \%$ of the first meeting and $38.5 \%$ of the second meeting (Mean $=39.25 \%, 22.5$ minutes) participating in the task. In the second meeting, for instance, all of the students were on task as they composed their own story after the reading of Amos and Boris' story. In that very limited of writing, all of the 32 students were able to submit their writing on time.

According to Gregory et al. (2014), observing students' behavioral engagement was by looking at their contributions to the classroom discussion, 
participating in academic tasks, and demonstrating their attention (by listening) towards teacher's instructions. In this study, it can be seen that all of the students showed positive behavioral engagement as they participated in listening, discussing, and doing the task. The dynamic type of activities guided by the teacher during the class which included interactive read-aloud might affect students' positive responses to every step of learning. Not to mention, as students were living in a dormitory who spent most of their time with their friends inside or outside classroom might create a safe space for them to be active in dialogues with each other. As such, teacher-student and peer relationships presented in the class were able to create a positive atmosphere which developed their behavioral engagement (Engels et al., 2016).

Table 1. Time spent on each meeting

\begin{tabular}{lcll}
\hline \multicolumn{1}{c}{$\begin{array}{c}\mathbf{1}^{\text {st }} \text { Meeting } \\
\text { Activities }\end{array}$} & \multicolumn{1}{c}{$\begin{array}{c}\text { Time spent } \\
\text { (in minutes) }\end{array}$} & \multicolumn{1}{c}{$\begin{array}{c}\mathbf{2}^{\text {nd }} \text { Meeting } \\
\text { Activities }\end{array}$} & \multicolumn{1}{c}{$\begin{array}{c}\text { time spent } \\
\text { (in minutes) }\end{array}$} \\
\hline $\begin{array}{l}\text { Ice breaking } \\
\text { discussion }\end{array}$ & 10 & $\begin{array}{l}\text { Ice breaking } \\
\text { discussion }\end{array}$ & 10 \\
\hline $\begin{array}{l}\text { Before reading } \\
\text { discussion }\end{array}$ & 10 & $\begin{array}{l}\text { Before reading } \\
\text { discussion }\end{array}$ & 10 \\
\hline $\begin{array}{l}\text { During reading } \\
\text { listening and discussion }\end{array}$ & 20 & $\begin{array}{l}\text { During reading } \\
\text { listening and discussion }\end{array}$ & 15 \\
\hline $\begin{array}{l}\text { After reading } \\
\text { Task: story analysis, focusing on } \\
\text { language features }\end{array}$ & 25 & $\begin{array}{l}\text { After reading } \\
\text { Task: writing a story after } \\
\text { the story }\end{array}$ & 20 \\
\hline $\begin{array}{l}\text { Closing } \\
\text { discussion }\end{array}$ & 5 & $\begin{array}{l}\text { Closing } \\
\text { discussion }\end{array}$ & 5 \\
\hline
\end{tabular}

\section{Cognitive Engagement}

There were three major cognitive engagements showed during the interactive read-aloud. First, students strategically tried to mix their languages while speaking. This engagement was also part of how students were making sense of foreign language input using their first language (Shin, 2017). When students expressed their opinion in English, they sometimes shifted their language in Indonesian if they didn't know a certain word or phrase in English. For example, one of the students argued, "it was similar because it's about hubungan yang saling menguntungkan... you know they help each other." The student forgot some words to say "mutual relationship" in English, so he chose to use Indonesian to share his thought.

In another situation, students tried to make sense of English language features that they had learned while they were delivering their perspectives. This occurred when they tried to use reported speech to describe the meaning of what a character in the book was saying. Also, one of the students tried to use a sophisticated vocabulary as they quoted the story event. He argued, “...but their body similarly got hurt because Boris was stranded, and his body similarly got hurt as what happened to Amos in the sea." He was able to come up with the word stranded although that word didn't exist in the story.

The third evidence was presented in their writing. They used their prior knowledge of English writing strategy in order to create their essay. Chart 1 presents students overall level performances of their essay. 


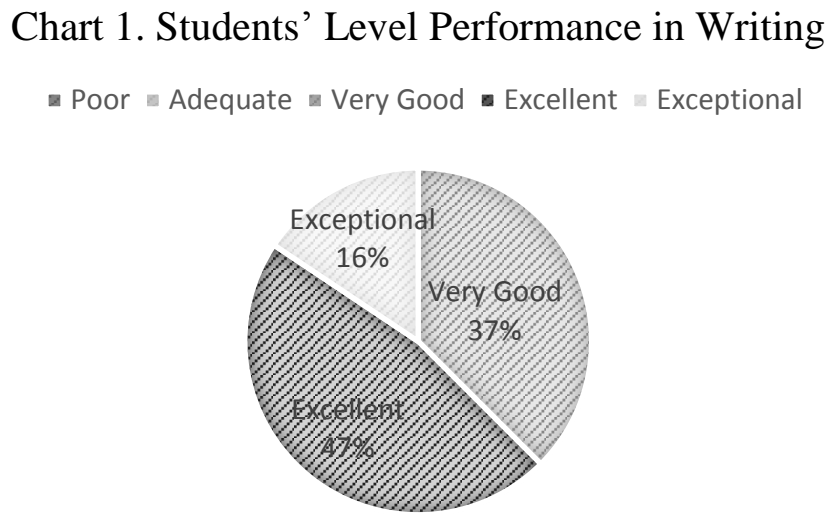

Students who were in the very good level indicated there were somewhat elaboration, lack of unity, and inconsistent use of language while excellent level of essay performance presented fair elaboration, well organization, and minor errors in the use of language. The exceptional level represented well organization, well unity, and consistent use of language. From the chart, none of students' essays were in level of poor and adequate. Although $37 \%$ of students showed a middle level of performance in writing, almost half of students performed their essay in level of excellent and $16 \%$ students exhibited their exceptional level of writing performance. As such, there were no students whose level of English writing was poor and adequate. Also, their plausible level of essay performance indicated their strategic use of prior knowledge of English writing to engage in the meantime essay activity.

Furthermore, the following language function analysis showed their ability to elaborate their sense making of reading in connection of their prior knowledge and other social contexts. Chart 2 presents the distribution of the use of language function in students' essay.

\section{Chart 2. Written Language Function Analysis}

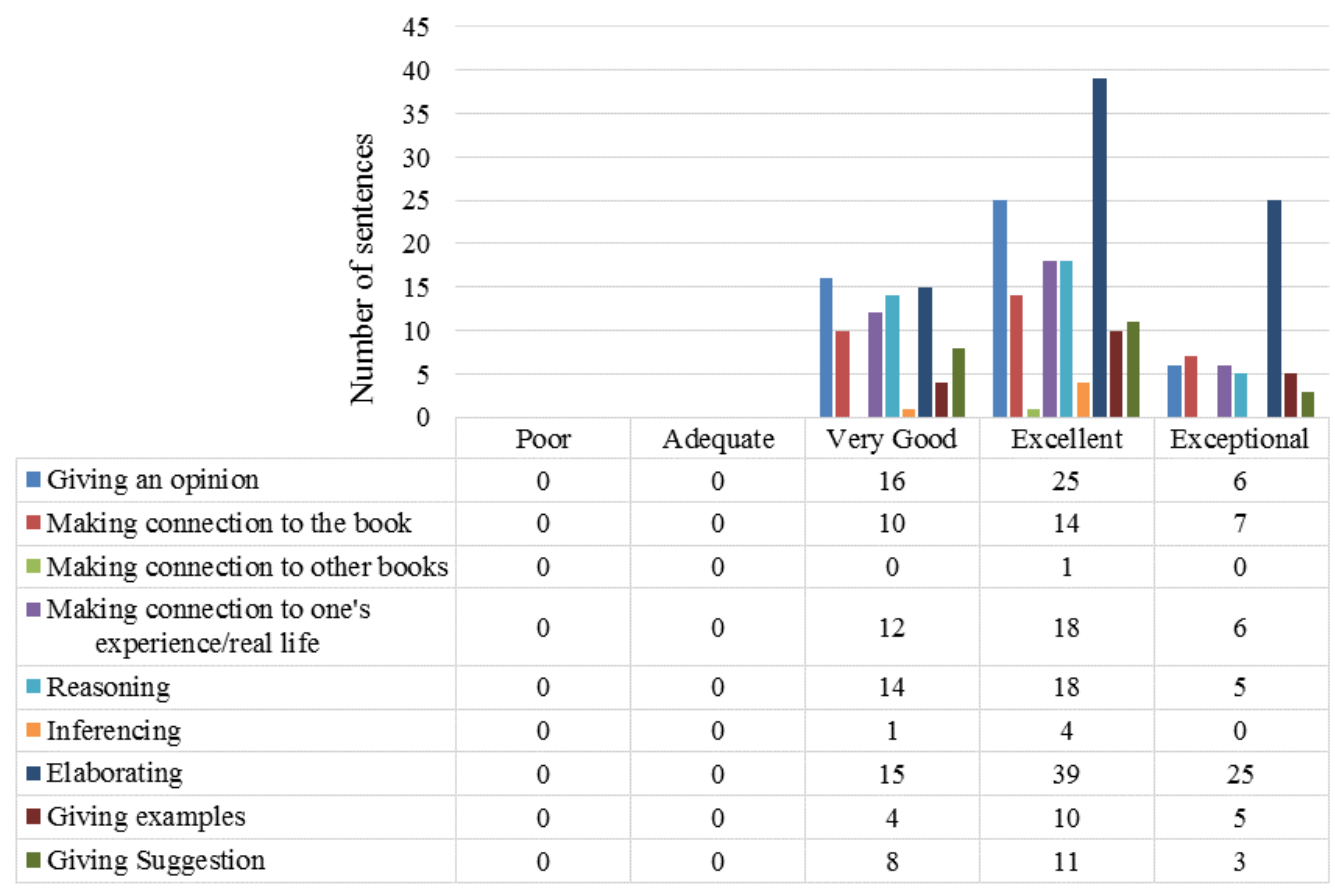


The chart shows that the highest number of language function used in students' essays was elaborating. This showed how students cognitively was able to use significance foreign language proficiency in written communication. This type of function appeared 15, 39, 25 times in each students' group level of essay. The next greatest number of language function were giving an opinion, making connections to book, and making connection one's experience/real life. The opinion students wrote in their sentences were all expressed their own impression after reading Amos and Boris. Most of students wrote that the story had moral values and other wrote it was an interesting story. As they were able to express their opinion about the reading, at the same time, they showed their engagement in participating within literacy event.

While students made connections to the book, most of them connected it with Amos and Boris and only 1 student connected it to The Lion and The Mouse. This was because they were allowed to freely choose the reading they wanted to refer back to. Besides, not all students were following Amos and Boris from the beginning. In connecting their writing to reading, some of them used indirect quote from the story. For example, one of the students wrote "Well from the story, I really enjoy the part where Amos was saved by Boris when Amos ship was sunken by the high tides, and Boris saved Amos in the brink of his death." As students created text in connection with other text(s), they profoundly were able to bring up intertextuality within their text (Fairclough, 1992).

Meanwhile, when students made connections to one's experience/real life, they shared how Amos and Boris' friendship was similar to their long-distance relationship with family and friends. One of the students wrote, "I have a similar friendship like Amos and Boris. I must study in Magelang and I must leave my friends in Jakarta." This emotional connection showed how students were able to make meaning of what they read in dialogue with what their similar experience of having a long-distance relationship. This showed how the student was able to wrap themselves into the story as they tried to draw upon his own life experience and understanding of reality (Gallas, 2003).

\section{Affective Engagement}

From the observation, it was noticed that some of the students clearly showed interest in the book and in the interactive read-aloud activity. First, it was when the class started and the students were told that we were going to read together at that time, students showed their excitement through their facial expression. They were more excited when I showed them the books that we were going to read. Another sign was when they kept quiet when I was reading. Also, some of them expressed amazement while we were exploring beautiful illustrations of the book. 
Figure 1. Understanding text from its context

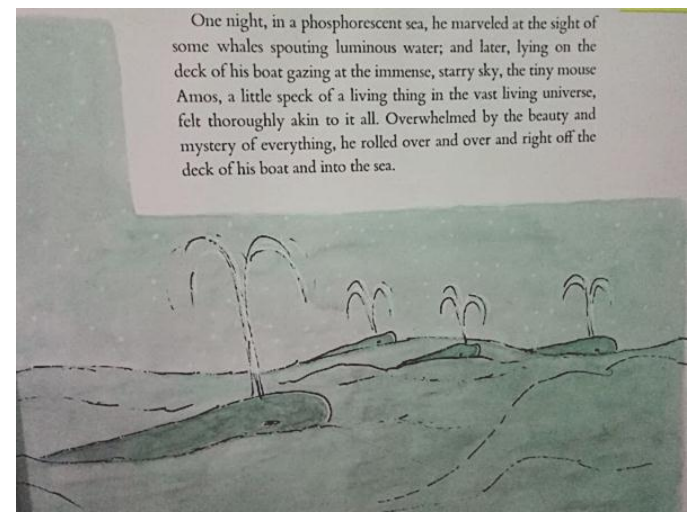

They also exhibited their interest in making sense with reading as they were curious about some unfamiliar vocabularies; then, they contextually tried to make meaning by referring to the illustration. When we discussed one page of the book of Amos and Boris (see figure 1), students were asked to guess the meaning the word "luminous", one of them was able to come up with its synonym "shiny." $\mathrm{He}$ explained that his answer was based on his interpretation from the illustration which presented the combination of bright color to describe the water splash at night. According to Sun (2020), the positive impacts of having interactive read-aloud from picture book on EFL learners were the development of reading attitudes and the use of text and prior knowledge to infer the meanings of unfamiliar words.

\section{CONCLUSION}

This short-term collaborative study exhibited evidence of how interactive read-aloud in EFL classroom could promote students' engagement and motivation to read. Students vividly presented their behavioral and cognitive engagement as they were participating in every classroom task and cognitively employed their English language proficiency in making sense the reading. Their affective engagement was also noticed through their facial expression and eagerness as they were enjoying reading aloud Amos and Boris. The description of students' engagement in this study signaled the mutual relationship with motivation (Guthrie et al., 1996). Similar to Guthrie et al. (1996) study, this study also cannot predict which one came first, motivation or engagement, because this study doesn't examine students' intrinsic motivation in this study. However, it is believed that developing engaging and meaningful reading activity such as interactive read-aloud continuously may promote students' intrinsic motivation to read (Gambrell, 2011).

Besides, the several limitations in this study should be addressed. First, this study was conducted using a specified class sample with small number of the students which made this study could not represent the regional or national population. Second, this study explored students' engagement in a short time period ( 2 meeting: 75 minutes and 65 minutes) which might not able to present profound evidence that could be easily generalizable. As such, the future research in the similar topic and context with larger participants and longer time period of exploration may be able to present more thorough discussion about various types 
of reading strategies which were able to develop students' engagement in EFL context.

\section{REFERENCES}

Brozo, W. G., Sulkunen, S., Shiel, G., Garbe, C., Pandian, A., \& Valtin, R. (2014). Reading, gender, and engagement. Journal of Adolescent \& Adult Literacy, 57(7), 584-593.

Engels, M. C., Colpin, H., Van Leeuwen, K., Bijttebier, P., Van Den Noortgate, W., Claes, S., ... \& Verschueren, K. (2016). Behavioral engagement, peer status, and teacher-student relationships in adolescence: A longitudinal study on reciprocal influences. Journal of Youth and Adolescence, 45(6), 1192-1207.

Fairclough, N. (1992). Discourse and social change. UK: Polity Press.

Fairclough, N. (2003). Analysing discourse: Textual analysis for social research. Psychology Press.

Fredricks, J. A., Blumenfeld, P. C., \& Paris, A. H. (2004). School engagement: Potential of the concept, state of the evidence. Review of educational research, 74(1), 59-109.

Gallas, K. (2003). Imagination and literacy: A teacher's search for the heart of learning. Teachers College Press.

Gambrell, L. B. (2011). Seven rules of engagement: What's most important to know about motivation to read. The Reading Teacher, 65(3), 172-178.

Gibson, S. (2008). Reading aloud: a useful learning tool? ELT Journal, 29-37.

Gregory, A., Allen, J. P., Mikami, A. Y., Hafen, C. A., \& Pianta, R. C. (2014). Effects of a professional development program on behavioral engagement of students in middle and high school. Psychology in the Schools, 51(2), 143-163.

Guthrie, J. T., Meter, P., McCann, A. D., Wigfield, A., Bennett, L., Poundstone, C. C., ... \& Mitchell, A. M. (1996). Growth of literacy engagement: Changes in motivations and strategies during concept-oriented reading instruction. Reading research quarterly, 31(3), 306-332.

Guthrie, J. T., \& Klauda, S. L. (2014). Effects of classroom practices on reading comprehension, engagement, and motivations for adolescents. Reading research quarterly, 49(4), 387-416.

Hoffman, J. L., Collins, M. F., \& Schickedanz, J. A. (2015). Instructional Challenges in Developing Young Children's Science Concepts: Using Informational Text Read-Alouds. Reading Teacher, 68(5), 363-372.

Ivey, G., \& Johnston, P. H. (2013). Engagement with young adult literature: Outcomes and processes. Reading Research Quarterly, 48(3), 255-275.

Johnston, V. (2016). Successful Read-Alouds in Today's Classroom. Kappa Delta Pi Record, 52(1), 39-42.

McMillan, James H. (2014). Classroom Assessment: Principles and Practice for Effective Standards-Based Instruction. Pearson.

Malloy, J.A., Parsons, S.A., \& Parsons, A.W. (2013). Methods for evaluating literacy engagement as a fluid construct. 62nd Yearbook of the Literacy Research Association, 124-139. 
Oueini, H., Bahous, R., \& Nabhani, M. (2008). Impact of read-aloud in the classroom: a case study. Reading, 8(1), 139-157.

Newman, F. M., Wehlage, G. G., \& Lamborn, S. D. (1992). Taking students seriously. Student engagement and achievement in American secondary schools. New York: teachers' college, Columbia University.

Parsons, S.A., Nuland, L.R., \& Parsons, A.W. (2014). The ABCs of student engagement. Phi Delta Kappan, 95(8), 23-27.

Parsons, S. A., Malloy, J. A., Parsons, A. W., \& Burrowbridge, S. C. (2015). Students' engagement in literacy tasks. The Reading Teacher, 69(2), 223231.

Pinkney, Jerry. (2000). Aesop's Fables. Chronicle Books.

Pinnell, Gay Su, and Scharer, Patricia L. (2001) Extending Our Reach: Teaching for Comprehension in Reading, Grades $K-2$. USA: The Ohio State University.

Sandy, F., \& Muliawanti, L. (2020). Komponen Interactive Read-Aloud dalam Konteks EFL. Proceeding of the URECOL, 253-261.

Shin, S. J. (2017). Bilingualism in schools and society: Language, identity, and policy. Routledge.

Silverman, R., Crandell, J. D., \& Carlis, L. (2013). Read alouds and beyond: The effects of read aloud extension activities on vocabulary in Head Start classrooms. Early Education \& Development, 24(2), 98-122.

Skinner, E. A., \& Pitzer, J. R. (2012). Developmental dynamics of student engagement, coping, and everyday resilience. In Handbook of research on student engagement (pp. 21-44). Springer US.

Steig, William. (1971). Amos and Boris. New York: Farrar, Straus and Giroux.

Sun, C. H. (2020). Using Interactive Picture-Book Read-Alouds with Middle School EFL Students. English Language Teaching, 13(7), 130-139.

Toth, A. (2013). Not Just for After Lunch. The Reading Teacher, 67(3), 203-207.

Trealease, Jim (2013). The Read-Aloud Handbook. USA: Penguin Books.

Worthy, J., Durán, L., Hikida, M., Pruitt, A., \& Peterson, K. (2013). Spaces for dynamic bilingualism in read-aloud discussions: Developing and strengthening bilingual and academic skills. Bilingual Research Journal, 36(3), 311-328. 